УДК 9

\title{
ИНТЕГРИРОВАННЫЙ УРОК ИСТОРИИ И МУЗЫКИ «АЛЕКСАНДР НЕВСКИЙ - СЛАВА, ДУХ И ИМЯ РОССИИ»
}

\section{Борисова Галина Владимировна \\ МАОУ «Гимназия №2» ГОЩ}

\begin{abstract}
Аннотация: Интегрированный урок учебных предметов история и музыка разработан в условиях реализации федерального государственного образовательного стандарта (ФГОС) с использованием технологии деятельностного метода. Урок составлен для учащихся 6 классов в рамках изучения предмета «История России» и соответствует календарнотематическому планированию.

Ключевые слова: «единство народа», «крестоносцы», «кантата», «оркестр», «хор»
\end{abstract}

\section{INTEGRATED LESSON HISTORY AND MUSIC «ALEXANDER NEVSKY - THE GLORY, SPIRIT AND NAME OF RUSSIA»}

\section{Borisova Galina Vladimirovna}

Abstract: An integrated lesson of academic subjects history and music was developed in the context of the implementation of the federal state educational standard (FGOS) using the technology of the activity method. The lesson is compiled for students in grades 6 , in the framework of the study of the subject "History of Russia" and corresponds to the calendar-thematic planning.

Key words: «Unity of the people», «crusaders», «cantata», «orchestra», «chorus»

Введение. Данный урок отражает общечеловеческую значимость идеи единства народа, показывает опасность войн и усобиц внутри страны. Содержит элементы гражданского, патриотического воспитания школьников. Формирует яркое образное представление об Александре Невском в одноименной кантате С. Прокопьева. Создает представление учащихся о важности отдельной личности человека в истории своей страны. 
Тип урока: Открытие новых знаний. Класс: 6

\section{Цели урока:}

- Образовательные:

- ввести и усвоить новые термины: «кантата», «музыкальная живопись», «живописная музыка»;

- расширить и закрепить знания о жизни и деятельности Александра Невского - яркой исторической личности, талантливого полководца, выдающегося политика;

- оценить значение творчества великого русского композитора С. Прокофьева в воплощении целостного образа русского народа как защитника Родины;

- провести анализ музыкальной формы, используя выразительные средства музыки: темп, регистр, тембр, мелодия, лад, интонация, динамика.

- Развивающие:

- формировать умения и творческие навыки каждого ученика;

- прививать бережное отношение к истории своего народа;

- показать многомерность и гармоничность различных видов искусства для создания образа Александра Невского.

- Воспитательные:

○ пробуждать и воспитывать патриотические чувства детей, гордость за героев Отечества;

- воспитывать чувство взаимовыручки и ответственности среди учащихся.

- на примере его жизни формировать у учащихся чувство гражданственности и патриотизма, уважения к историческому прошлому; прививать осязание глубиной мудрости родного слова

УУД

\section{Познавательные:}

- находить в источниках информацию необходимую для решения задач,

- анализировать документы и делать выводы,

- устанавливать причинно-следственные связи.

\section{Регулятивные}

- определять цель и проблему учебной деятельности,

- выдвигать версии,

- находить и исправлять ошибки,

- работать по плану, сверяясь с целью. 


\section{Коммуникативные}

- $\quad$ корректировать свое мнение под влиянием контраргументов.

\section{Оборудование урока:}

- историческая карта «Борьба русского народа с иноземными захватчиками в начале XIII в.»

- запись кантаты С. Прокопьева «Александр Невский»

- картины: П. Корин «Александр Невский», А. Горбунов «Ледовое побоище»

- схема Ледового сражения

- Фрагмент Ледовое побоище (фильм С.Эйзенштейна Александр Невский 1938 год)

- Презентация к уроку «Александр Невский»

- Интерактивная доска и мультимедийный проектор

Важнейшие события и основные даты:

- Невская битва июль 1240

- Ледовое побоище 5 апреля 1242

\section{Средства, используемые на уроке:}

- презентация «Александр Невский».

- текст хрестоматии «Рассказы по русской истории» (приложение 1)

- фрагмент поэмы К. Симонова «Ледовое побоище» (приложение 2)

\section{На уроке использованы:}

1. Отрывки из кантаты С. Прокофьева («А и было дело», «Вставайте, люди русские», «На Руси родной», «Мертвое поле», «Я пойду по полю белому»).

2. Отрывки из фильма С. Эйзенштейна «Александр Невский».

3. Репродукции картин: М. Нестеров «Александр Невский», П. Корин «Северная легенда» (триптих), В. Серов «Въезд Александра Невского во Псков после Ледового побоища».

4. Икона «Святой Благоверный князь Александр Невский».

5. Духовное песнопение «Величание Александру».

\section{Приёмы работы, используемые на уроке:}

сравнение, анализ иллюстраций, работа с контурной картой, сюжетный анализ просмотренного видеоматериала (фильма). 


\begin{tabular}{|c|c|c|c|}
\hline Этапы урока & Действия учителя & Действия учеников & $\begin{array}{c}\text { Формирование УУД, } \\
\text { технология } \\
\text { оценивания }\end{array}$ \\
\hline $\begin{array}{l}\text { І. Мотивация к } \\
\text { учебной } \\
\text { деятельности. }\end{array}$ & $\begin{array}{l}\text { Учитель музыки: Исполняет } \\
\text { молитву Александру Невскому на } \\
\text { фортепьяно } \\
\text { Как вы думаете, где может } \\
\text { исполняться этот музыкальный } \\
\text { фрагмент? Кем он может } \\
\text { исполняться? кому он был посвящен? } \\
\text { (приложение) }\end{array}$ & $\begin{array}{l}\text { Подготовка к } \\
\text { работе, включение в } \\
\text { деловой ритм. }\end{array}$ & \\
\hline $\begin{array}{l}\text { IІ. Актуализация } \\
\text { знаний и } \\
\text { фиксирование } \\
\text { индивидуального } \\
\text { затруднения в } \\
\text { пробном учебном } \\
\text { действии. }\end{array}$ & $\begin{array}{l}\text { Учитель истории: В истории нашего } \\
\text { Отечества много ярких событий и } \\
\text { значимых страниц. С некоторыми из } \\
\text { них вы уже познакомились, а } \\
\text { некоторые вам только предстоит } \\
\text { изучить. Это и великие победы, и } \\
\text { яркие исторические деятели. } \\
\text { Почему Александр Невский считается } \\
\text { выдающимся и значимым в истории } \\
\text { человеком? Какую роль он сыграл в } \\
\text { истории нашего государства? За какие } \\
\text { заслуги Православная церковь } \\
\text { причислила благоверного князя } \\
\text { Александра, к лику святых. } \\
\text { Учитель музыки: } \\
\text { Почему образ князя вдохновлял в } \\
\text { разные периоды истории } \\
\text { композиторов, поэтов, художников и } \\
\text { скульпторов? } \\
\text { (Активизация познавательного } \\
\text { интереса, создание проблемной } \\
\text { ситуации). } \\
\text { Пробное задание: } \\
\text { Учитель истории: Почему в ХХ } \\
\text { веке, спустя } 7 \text { веков с того периода } \\
\text { когда жил князь Александр } \\
\text { Невский, его образ вновь } \\
\text { становится актуальным и особенно } \\
\text { значимым для народа нашей } \\
\text { страны? } \\
\text { Учитель музыки: } \\
\text { Почему советский кинорежиссер } \\
\text { Сергей Эйзенштейн и композитор } \\
\text { Сергей Прокофьев выбирали образ } \\
\text { героя-князя для создания фильма и } \\
\text { кантаты в 30-е годы ХХ ? }\end{array}$ & $\begin{array}{l}\text { Затруднения } \\
\text { - Я не..... } \\
\text { - Я не .... } \\
\text { - Я не уверен что } \\
\ldots . \\
\text { Причины } \\
\text { затруднений: } \\
\text { - Я не знаю ... }\end{array}$ & $\begin{array}{l}\text { Регулятивные УУД } \\
\text { 1. Определять цель, } \\
\text { проблему в учебной } \\
\text { деятельности. } \\
\text { 2. Выдвигать версии. } \\
\text { 3. Планировать } \\
\text { деятельность в учебной } \\
\text { ситуации. } \\
\text { 4. Оценивать степень и } \\
\text { способы достижения } \\
\text { цели в учебной } \\
\text { ситуации. } \\
\text { Познавательные УУд } \\
\text { 1. Находить } \\
\text { достоверную } \\
\text { информацию в разных } \\
\text { источниках (тексты } \\
\text { учебника, схемы). } \\
\text { 2. Анализировать } \\
\text { (выделять главное). } \\
\text { 3. Определять понятия. } \\
\text { 4. Обобщать, делать } \\
\text { выводы. } \\
\text { 5. Выделять причины и } \\
\text { следствия. } \\
\text { 6. Представлять } \\
\text { информацию в разных } \\
\text { формах (схема, } \\
\text { таблица). } \\
\text { Коммуникативные } \\
\text { УУд } \\
\text { 1. Умение работать в } \\
\text { парах. } \\
\text { 2. Излагать своё }\end{array}$ \\
\hline
\end{tabular}




\begin{tabular}{|c|c|c|c|}
\hline $\begin{array}{l}\text { III. Выявление } \\
\text { места и причины } \\
\text { затруднения. }\end{array}$ & $\begin{array}{l}\text { Учитель истории: Какую задачу } \\
\text { будем решать? Что, по вашему } \\
\text { мнению, нужно узнать, чтобы найти } \\
\text { решение проблемы? Как будет } \\
\text { сегодня называться тема урока? }\end{array}$ & $\begin{array}{l}\text { Формулируют } \\
\text { задачу, предлагают } \\
\text { способы ее } \\
\text { решения. } \\
\text { - узнать почему } \\
\text { князь Александр } \\
\text { Невский признан } \\
\text { народным героем. } \\
\text { - Выяснить, как } \\
\text { события его жизни, } \\
\text { а также его } \\
\text { поступки повлияли } \\
\text { на историю нашего } \\
\text { Отечества. } \\
\text { Определить итоги } \\
\text { его княжеской } \\
\text { деятельности. } \\
\text { - выяснить, почему } \\
\text { образ князя стал } \\
\text { источником } \\
\text { вдохновения многих } \\
\text { деятелей культуры } \\
\text { и искусства в ХХ } \\
\text { веке. } \\
\text { - Продолжить } \\
\text { учиться работать с } \\
\text { историческими } \\
\text { документами. } \\
\text { Тема урока: Князь } \\
\text { Александр Невский }\end{array}$ & $\begin{array}{l}\text { мнение, аргументируя } \\
\text { его. } \\
\text { 3. Создавать устные и } \\
\text { письменные тексты. } \\
\text { 4. Использовать } \\
\text { речевые средства в } \\
\text { соответствии с } \\
\text { ситуацией общения. } \\
\text { Личностные УУд } \\
\text { 1. Оценивать свои и } \\
\text { чужие поступки. }\end{array}$ \\
\hline & $\begin{array}{l}\text { Учитель музыки: } \\
\text { Более семи веков прошло с тех пор, но } \\
\text { и сегодня не ослабевает интерес к } \\
\text { личности князя Александра. Его образ } \\
\text { воплощали в произведениях } \\
\text { литературы, живописи, музыки, } \\
\text { кинематографии. } \\
\text { Среди них особое место занимает } \\
\text { героическая кантата С. Прокофьева } \\
\text { «Александр Невский». Давайте } \\
\text { вспомним из ранее изученного } \\
\text { материала, что означает понятие } \\
\text { кантата. } \\
\text { Учитель музыки: Что такое кантата? } \\
\text { Музыкальные фрагменты кантаты } \\
\text { позволят нам составить портрет } \\
\text { национального героя и полководца } \\
\text { князя Александра Ярославовича. }\end{array}$ & $\begin{array}{l}\text { Кантата - это } \\
\text { музыкальное } \\
\text { произведение для } \\
\text { хора, солистов, } \\
\text { симфонического } \\
\text { оркестра, состоящее } \\
\text { из нескольких } \\
\text { частей, связанных } \\
\text { по смыслу. }\end{array}$ & $\begin{array}{l}\text { Аргументировать свою } \\
\text { точку зрения. Делать } \\
\text { выводы, извлекать } \\
\text { информацию из } \\
\text { различных источников. }\end{array}$ \\
\hline
\end{tabular}




\begin{tabular}{|c|c|c|c|}
\hline & $\begin{array}{l}\text { Учитель истории: } \\
\text { А теперь обратимся к истории и } \\
\text { вспомним события, которые } \\
\text { происходили на Руси в начале ХІІІ } \\
\text { века. Кто такие монголо-татары? И } \\
\text { какие события, связанные с ними, } \\
\text { произошли в этот период на Руси? } \\
\text { Почему монголо-татары смогли } \\
\text { подчинить себе русские княжества? }\end{array}$ & $\begin{array}{l}\text { Орды монголо-татар } \\
\text { под } \\
\text { предводительством } \\
\text { Батыя вторглись на } \\
\text { Русь. Многие } \\
\text { русские княжества } \\
\text { были захвачены, } \\
\text { города были } \\
\text { сожжены, население } \\
\text { перебито или } \\
\text { угнано в рабство. } \\
\text { Княжества обязаны } \\
\text { были платить дань } \\
\text { ханам Золотой } \\
\text { орды. } \\
\text { Русь была } \\
\text { раздроблена, князья } \\
\text { враждовали друг с } \\
\text { другом. Они не } \\
\text { сумели } \\
\text { объединиться, } \\
\text { поэтому княжества } \\
\text { и были завоеваны. } \\
\text { Русь опустошена, } \\
\text { обескровлена. } \\
\text { Чувства скорби и } \\
\text { отчаяния наполняли } \\
\text { души людей. }\end{array}$ & $\begin{array}{l}\text { Понимать на слух } \\
\text { ответы обучающихся. } \\
\text { Слушать } \\
\text { собеседника. }\end{array}$ \\
\hline $\begin{array}{l}\text { IV. Построение } \\
\text { проекта выхода } \\
\text { из затруднения. }\end{array}$ & $\begin{array}{l}\text { Учитель истории: (рассказ по карте) } \\
\text { В это же самое время с запада на Русь } \\
\text { вторглись шведские и немецкие } \\
\text { рыцари-крестоносцы. Они хотели } \\
\text { завоевать псковские и новгородские } \\
\text { земли. } \\
\text { Чем же их привлекали эти города? }\end{array}$ & $\begin{array}{l}\text { Это были богатые } \\
\text { торговые города. }\end{array}$ & \\
\hline & $\begin{array}{l}\text { рыцари-крестоносцы. Они хотели } \\
\text { завоевать псковские и новгородские } \\
\text { земли. } \\
\text { Чем же их привлекали эти города? } \\
\text { Прочитайте текст хрестоматии и } \\
\text { ответьте на вопрос: Как удалось } \\
\text { молодому князю Александру } \\
\text { Ярославовичу одолеть шведов с } \\
\text { небольшим отрядом воинов? } \\
\text { Каким был молодой князь? } \\
\text { Слайд } 7 \\
\text { Приложение 1 } \\
\text { Текст: Шведские рыцари в июле } \\
1240 \text { года высадились отрядом в устье } \\
\text { Невы, они хотели овладеть землями } \\
\text { по берегам Финского залива, при это } \\
\text { под угрозой нападения оказался город }\end{array}$ & $\begin{array}{l}\text { Предполагаемый } \\
\text { ответ: } \\
\text {-внезапность } \\
\text { нападения, } \\
\text { - шведы не успели } \\
\text { закрепиться на } \\
\text { берегу. } \\
\text { - «Высокий рост, } \\
\text { красивая } \\
\text { внешность, голос } \\
\text { гремел перед } \\
\text { народом как труба». }\end{array}$ & $\begin{array}{l}\text { Строить } \\
\text { понятные для } \\
\text { собеседника } \\
\text { высказывания. } \\
\\
\text { Осуществлять анализ с } \\
\text { целью нахождения } \\
\text { соответствия } \\
\text { заданному эталону. }\end{array}$ \\
\hline
\end{tabular}




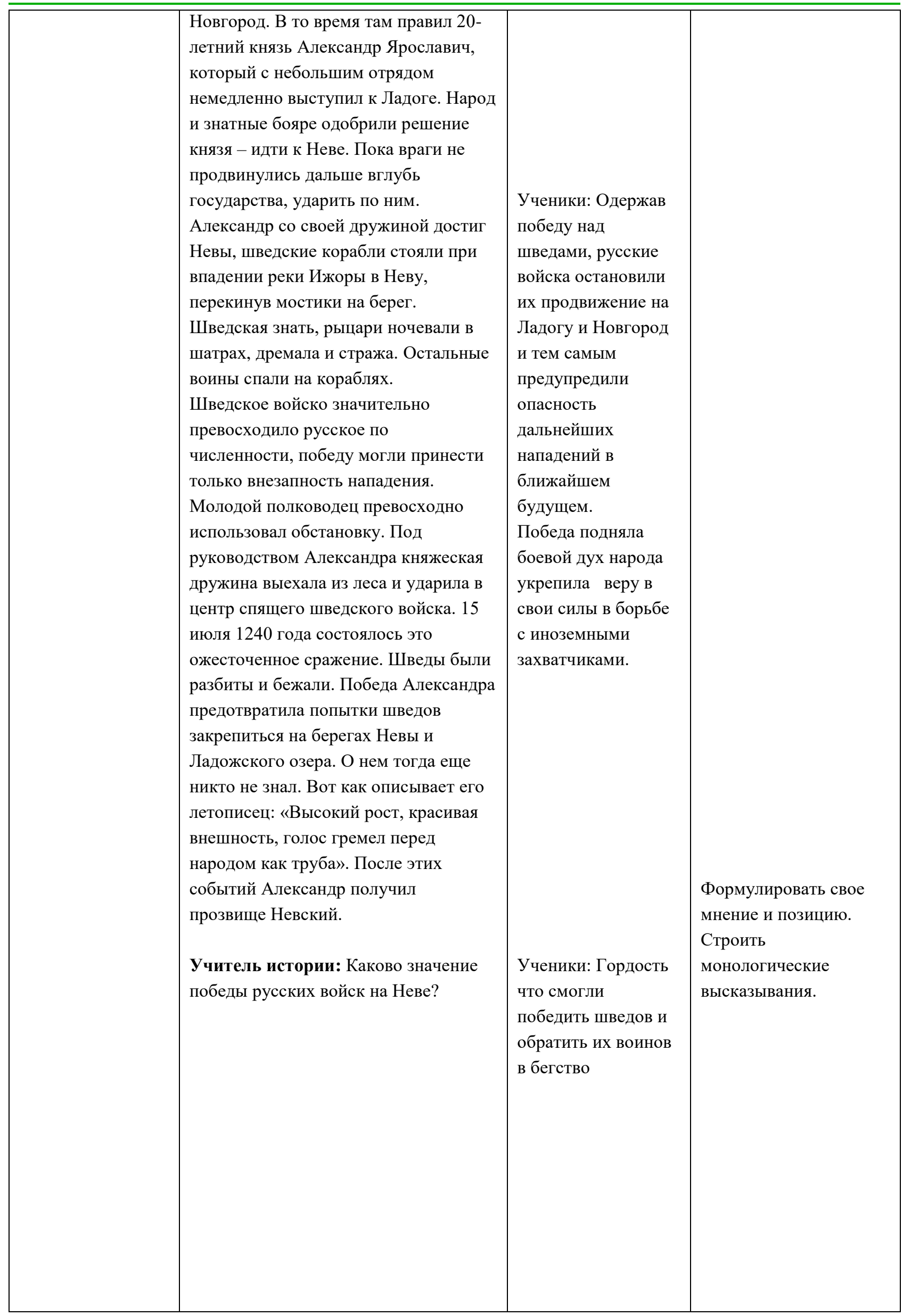




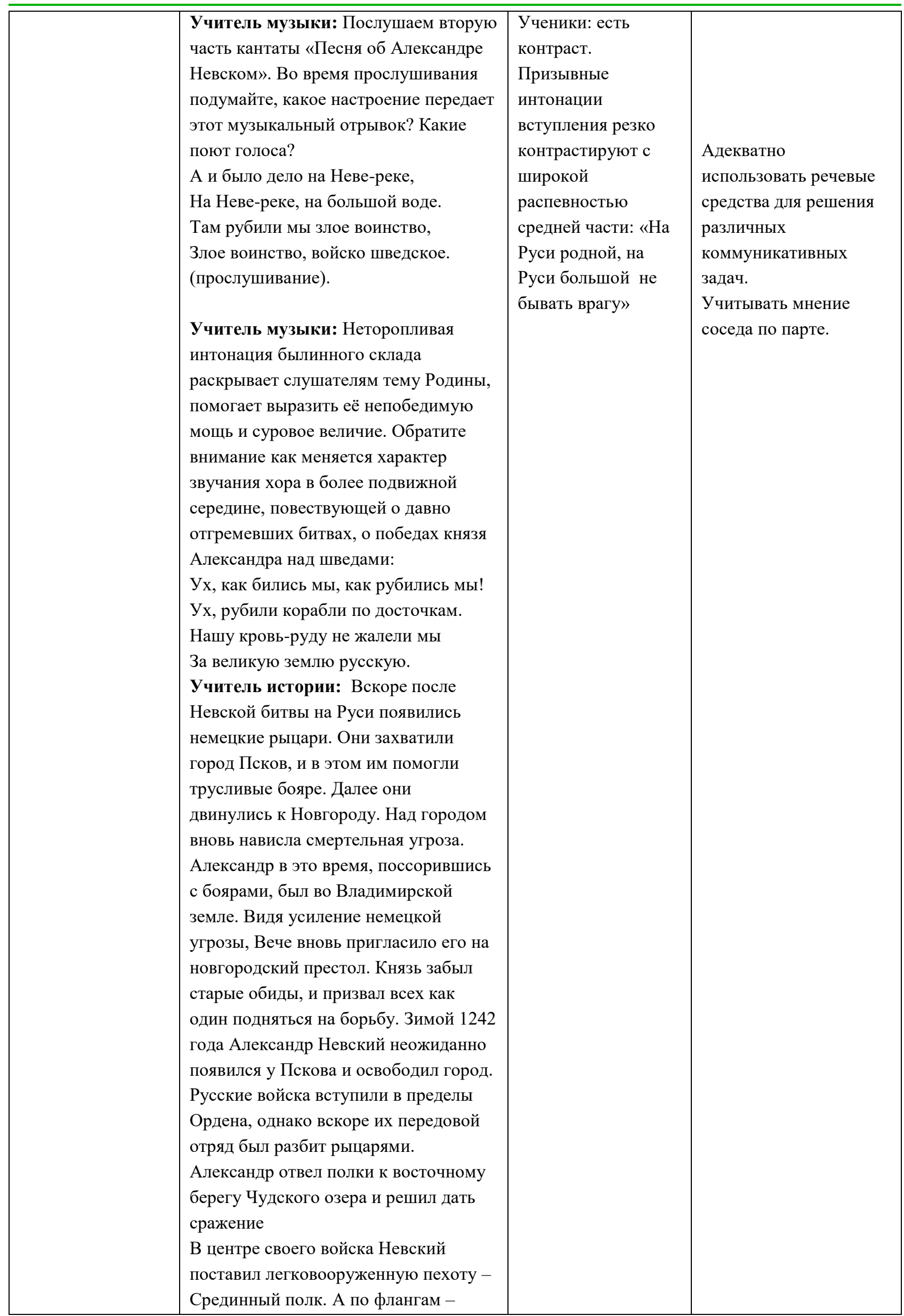




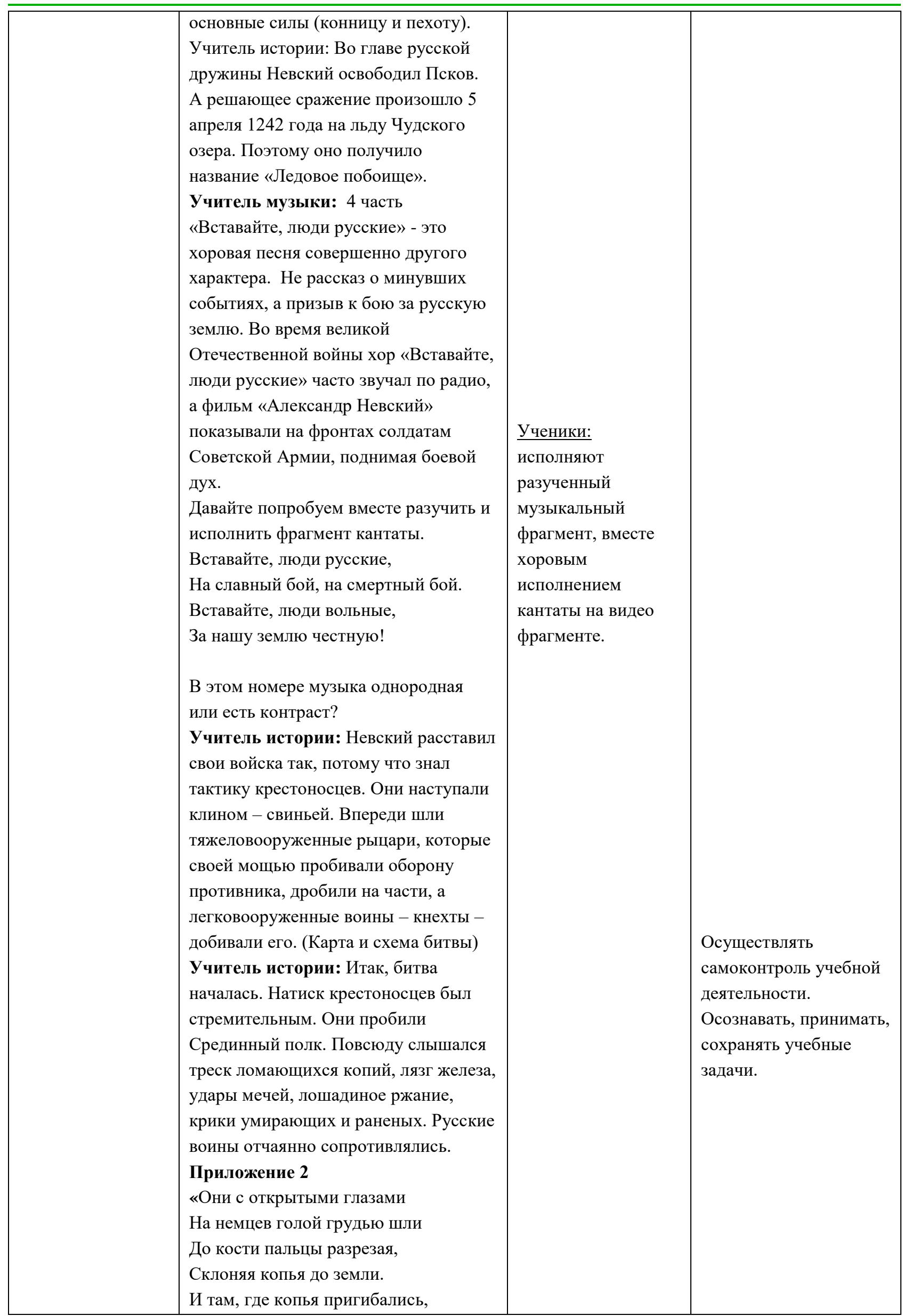




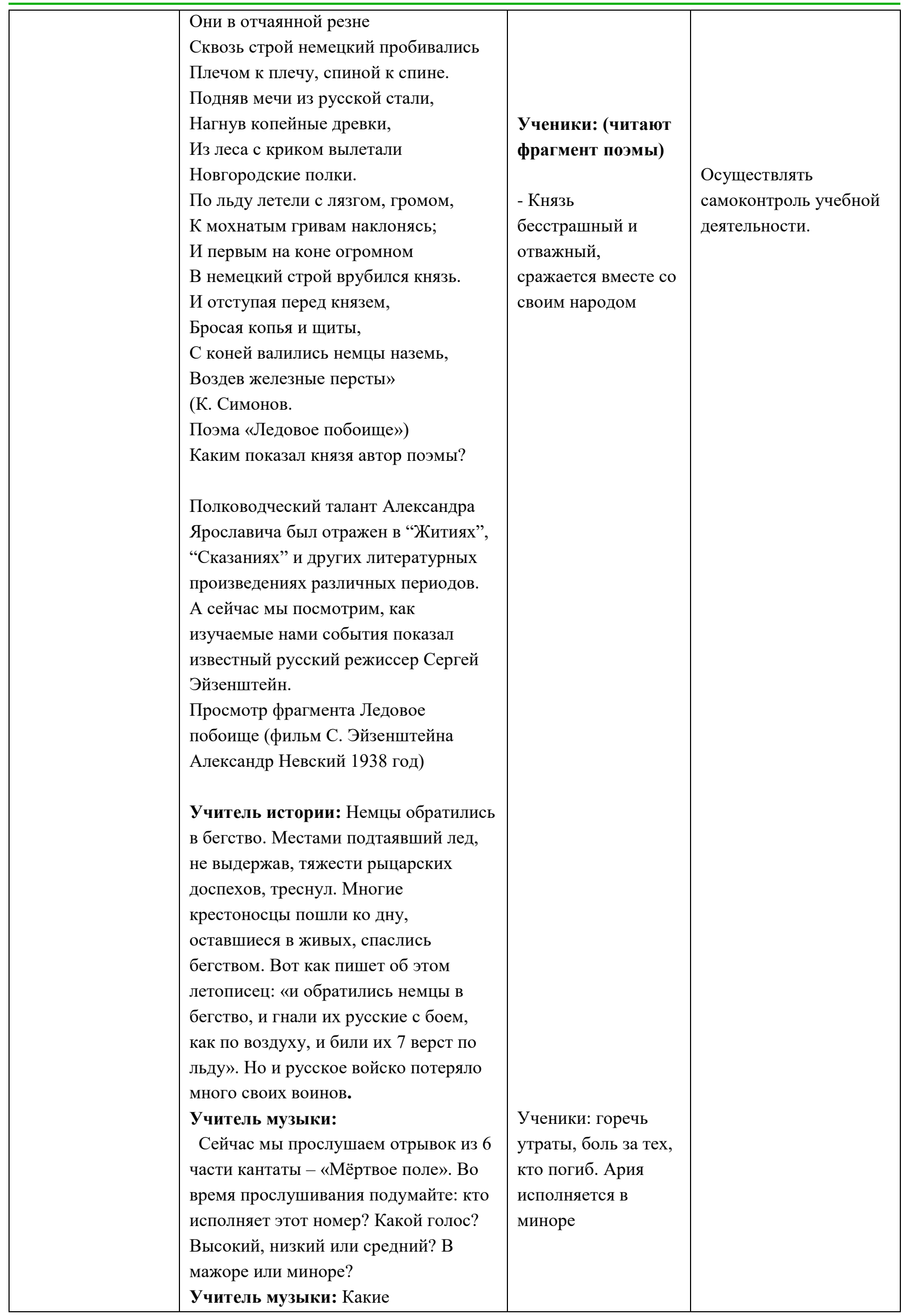




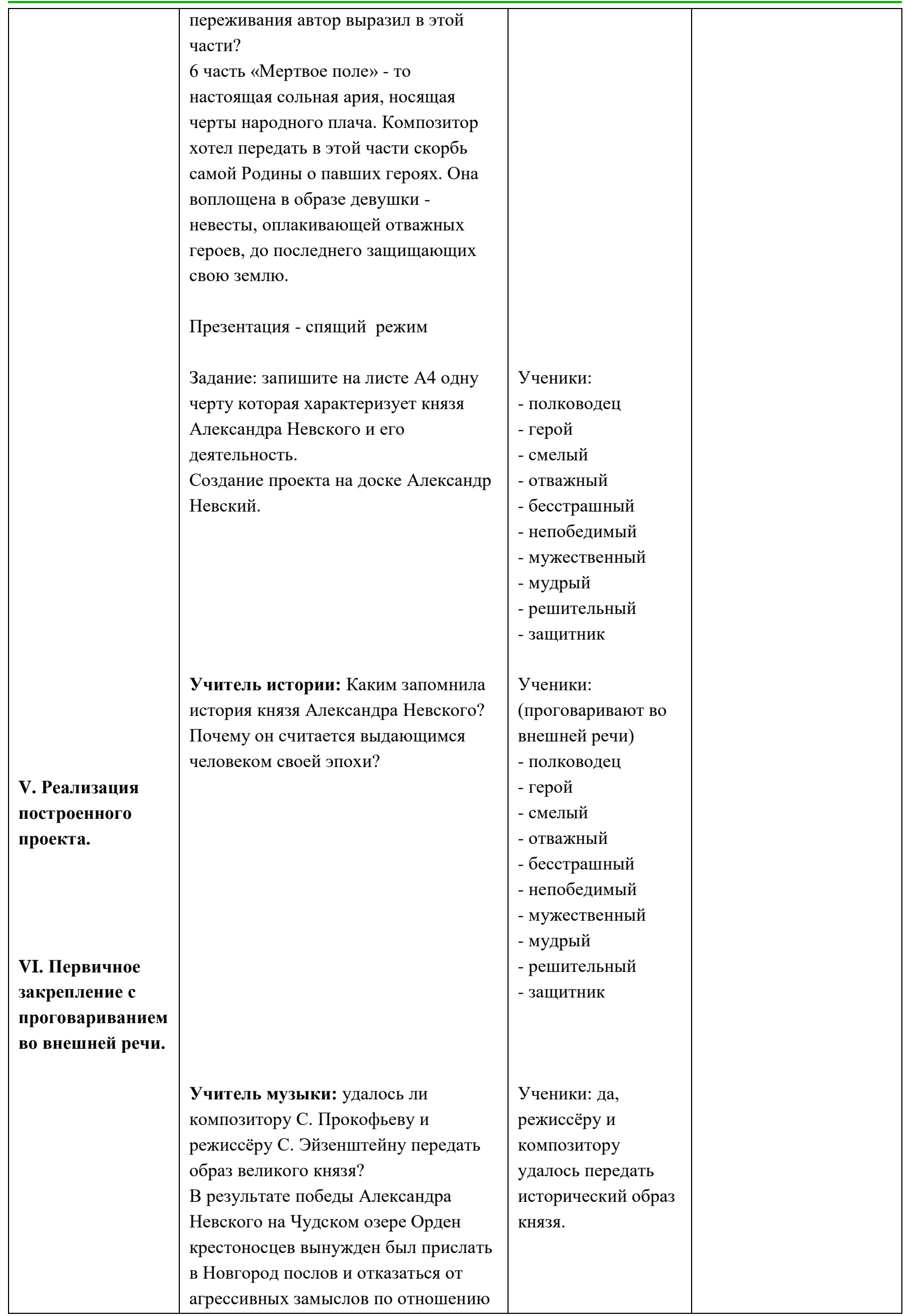


VII. Включение в систему знаний на повторение. к землям Руси. Победа над орденом имела и иное значение: она положила предел попыткам Европы навязать Руси католицизм. Александр Невский стал безусловным героем своего времени. Но, несмотря на свои победы и полководческий талант, выступить против монголо-татар Невский не решился. Слишком слаба была еще Русь, слишком силен враг.

Александр навечно остался в памяти народной, и был причислен к лику святых. Петр I заложил вблизи СанктПетербурга Александро-Невскую лавру и перенес туда мощи святого князя. Он же учредил орден в честь Невского.

В годы Великой Отечественной войны также был учрежден орден Александра Невского, которым награждали храбрых офицеров. Слайд 19

\section{Закрепление нового материала}

Фронтальная беседа по вопросам. - Почему удалось отстоять северозападные рубежи Руси?

- Какое значение имели битвы 1240 и 1242 гг.?

- Как вы думаете, почему в Великую Отечественную войну был учрежден орден Александра Невского?

Учитель музыки: давайте в заключении нашего урока послушаем и посмотрим отрывок кантаты, «Въезд Александра во Псков». В этом эпизоде прославляется Русь-победительница, а также проходят светлые темы из второй, четвертой и пятой части. В
Ученики:

1. русские люди смогли объединиться 2.полководческий талант Александра 3. героизм русских воинов

Ученики: Укрепили боевой дух русского народа. Невская битва и Ледовое побоище явились крупной исторической вехой в развитии северозападных земель и в целом Руси. Это еще одно свидетельство непоколебимого мужества русского народа в борьбе с иноземными захватчиками. Ученики: Александр Невский 


\begin{tabular}{|c|c|c|c|}
\hline & $\begin{array}{l}\text { целом этот хор носит гимнический } \\
\text { характер. } \\
\text { Прослушивание... Кто исполняет эту } \\
\text { часть? }\end{array}$ & $\begin{array}{l}\text { боролся с } \\
\text { западными } \\
\text { завоевателями. Он } \\
\text { стал символом } \\
\text { храбрости и } \\
\text { патриотизма в } \\
\text { борьбе с немецкими } \\
\text { захватчиками. В } \\
\text { период Великой } \\
\text { Отечественной } \\
\text { войны эти качества } \\
\text { и этот образ } \\
\text { должны были стать } \\
\text { идеалом и образцом } \\
\text { для подражания. } \\
\text { Ученики: } \\
\text { Оркестр и хор }\end{array}$ & \\
\hline $\begin{array}{l}\text { VIII. Рефлексия } \\
\text { учебной } \\
\text { деятельности }\end{array}$ & $\begin{array}{l}\text { - понравился ли вам урок? } \\
\text { - удалось ли решить поставленные в } \\
\text { начале урока задачи? } \\
\text { - что нового о князе Александре } \\
\text { Невском вы узнали на уроке? } \\
\end{array}$ & & $\begin{array}{l}\text { Осознавать, принимать, } \\
\text { сохранять учебные } \\
\text { задачи }\end{array}$ \\
\hline $\begin{array}{l}\text { IX. Домашнее } \\
\text { задание. }\end{array}$ & Повторить изученную тему. & & $\begin{array}{l}\text { Осознавать, принимать, } \\
\text { сохранять учебные } \\
\text { задачи }\end{array}$ \\
\hline
\end{tabular}

Заключение. Князь Александр Невский своими ратными подвигами навсегда прославил русское воинство во всем мире. Историческую ценность и значимость двукратного отражения Александром Невским отрядов крестоносцев на реке Неве и Чудском озере невозможно недооценить. Это были действительно крупные победы России над иностранными европейскими захватчиками, на время остудившие пыл европейских агрессоров в своих притязаниях на территорию

Приложение 1

Текст: Шведские рыцари в июле 1240 года высадились отрядом в устье Невы, они хотели овладеть землями по берегам Финского залива, при этом под угрозой нападения оказался город Новгород. В то время там правил 20-летний князь Александр Ярославич, который с небольшим отрядом немедленно выступил к Ладоге. Народ и знатные бояре одобрили решение князя - идти к Неве. Пока враги не продвинулись дальше вглубь государства, ударить по ним. Александр со своей дружиной достиг Невы, шведские корабли стояли при 
впадении реки Ижоры в Неву, перекинув мостики на берег. Шведская знать, рыцари ночевали в шатрах, дремала и стража. Остальные воины спали на кораблях.

Шведское войско значительно превосходило русское по численности, победу могли принести только внезапность нападения. Молодой полководец превосходно использовал обстановку. Под руководством Александра княжеская дружина выехала из леса и ударила в центр спящего шведского войска. 15 июля 1240 года состоялось это ожесточенное сражение. Шведы были разбиты и бежали. Победа Александра предотвратила попытки шведов закрепиться на берегах Невы и Ладожского озера. О нем тогда еще никто не знал. Вот как описывает его летописец: «Высокий рост, красивая внешность, голос гремел перед народом как труба». После этих событий Александр получил прозвище Невский.

Приложение 2

«Они с открытыми глазами

На немцев голой грудью шли

До кости пальцы разрезая,

Склоняя копья до земли.

И там, где копья пригибались,

Они в отчаянной резне

Сквозь строй немецкий пробивались

Плечом к плечу, спиной к спине.

Подняв мечи из русской стали,

Нагнув копейные древки,

Из леса с криком вылетали

Новгородские полки.

По льду летели с лязгом, громом,

К мохнатым гривам наклонясь;

И первым на коне огромном

В немецкий строй врубился князь.

И отступая перед князем,

Бросая копья и щиты,

С коней валились немцы наземь,

Воздев железные персты»

(К. Симонов. Поэма «Ледовое побоище») 


\section{Список литературы}

1. Алексеев С.П. Хрестоматия. Рассказы по русской истории, Дрофа Плюс 2007

2. Электронная библиотека мультимедиа учебника «Родная история»

3. Ю.Н. Бегунов, А.Н. Кирпичников. Князь Александр Невский и его эпоха. - Сборник трудов. - СПб.: Дмитрий Буланин, 1995. - С. 206. - 214 с.

4. Клепинин Н. Святой и благоверный великий князь Александр Невский. Москва, Стрижев - 1993 г., С. 14.

5. Данилевский И.Н. Ледовое побоище: смена образа // Отечественные записки. - 2004. - № 5. 